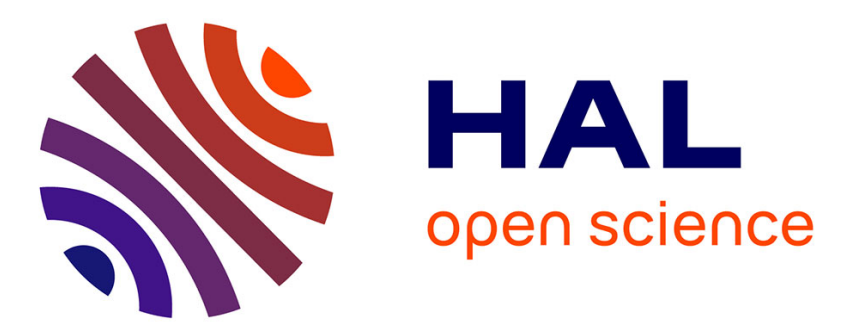

\title{
Vertical Product Line Extension Strategies: An Evaluation of Brand Halo Effect according to Range Level
}

Eric Tafani, Géraldine Michel, Emmanuelle Rosa

\section{- To cite this version:}

Eric Tafani, Géraldine Michel, Emmanuelle Rosa. Vertical Product Line Extension Strategies: An Evaluation of Brand Halo Effect according to Range Level. Recherche et Applications en Marketing (English Edition), 2009, 24 (2), pp.73-88. hal-02051232

\section{HAL Id: hal-02051232 https://hal.science/hal-02051232}

Submitted on 27 Feb 2019

HAL is a multi-disciplinary open access archive for the deposit and dissemination of scientific research documents, whether they are published or not. The documents may come from teaching and research institutions in France or abroad, or from public or private research centers.
L'archive ouverte pluridisciplinaire HAL, est destinée au dépôt et à la diffusion de documents scientifiques de niveau recherche, publiés ou non, émanant des établissements d'enseignement et de recherche français ou étrangers, des laboratoires publics ou privés. 


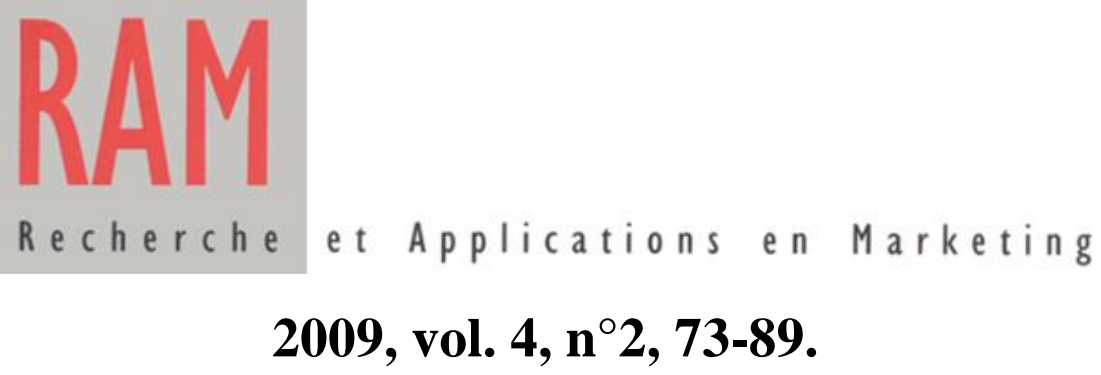

\title{
Vertical Product Line Extension Strategies: an Evaluation of Brand Halo Effect according to Range Level
}

\author{
Eric Tafani, IAE Aix, Aix-Marseille University \\ Géraldine Michel, IAE Paris, Paris I Panthéon-Sorbonne University \\ Emmanuelle Rosa, University of Provence
}

\begin{abstract}
The brand halo effect for vertical product line extensions is analyzed using the central nucleus theory. The empirical study is based on experimentation linked to six brands in the automotive sector. This research shows that central brand associations are transferred to the vertical product line extension regardless of range level - low, middle or high-end range - and that such transference systematically reinforces linkages between such associations and the product line extensions. In contrast, the transfer of peripheral associations appears to be range-dependent, increasing or decreasing linkages between such associations and the product line extension according to the range level considered.
\end{abstract}

Key words: Vertical product line extension, brand image, halo effect, social representations, central nucleus theory. 


\section{INTRODUCTION}

The brand is a distinctive sign meant to ensure differentiation vis-à-vis of competitive products, providing added value to the branded product (Farquhar, 1990). Over the past twenty years, the brand has emerged as a new form of capital upon which companies rely to launch new products or services. The vertical product line extension strategy has become a common practice for companies seeking to provide a range of products under an existing trademark - from entry-level to premium products - for product categories where branding is a differentiating factor (Keller, 2008). The vertical product line extension represents a new product entry for a brand with levels of performance and prices significantly different from existing ranges of products (e.g., Apple MP3 players under the brands Nano and Shuffle, sold for $40 \%$ to $50 \%$ less than Apple's lead brand, iPod). Our research focuses on the vertical product line extension strategy, a strategy that, despite extensive development, remains little studied.

Research has shown that the evaluation of vertical product line extensions was influenced by (1) new product launches (Kim, Lavack and Smith, 2001), (2) functional and symbolic brand characteristics (Kim, Lavack and Smith, 2001; Kirmani, Sood and Bridges, 1997; Randall, Ulrich and Reibstein, 1999) and finally, (3) relationships between the product line extension and existing products of the brand (Gochen and Yung-Ghien, 2007; Kim and Chhajed, 2001). To our knowledge, no research has studied the effect of the brand image in evaluating vertical brand extensions. Several important questions remain: What is the influence of branding on the perception of the product extension? Does image transfer from brand to extension depend on the vertical position within the product range? Finally, how does this image transfer affect perceptions of the vertical product line extension? On these points, several models of brand equity agree on the need to separate the effect of the brand on the evaluation of the branded extension (halo effect), as well as its effect in terms of preference for branded extension (Park and Srinivasan, 1994). Even so, the question of range level and brand image dependence remains open to debate.

Our research aims to illuminate these issues on the basis of the theory of social representations (Moscovici, 1976) and more particularly using Central Nucleus Theory (Abric, 1994). The significance of this theoretical framework is, on the one hand, to postulate that the brand image is based on a social construct which is a reflection of consumer attitudes toward the studied product category (Moliner, 1996), and on the other hand, to introduce the 
distinction between central and peripheral brand associations (Michel, 1999). Several studies have shown the adaptive function of the peripheral system that makes it possible to incorporate changing brand practices, while demonstrating the stability of brand core system that ensures image continuity (Michel 1999; Michel and Cegarra, 2002; Aimé, 2007; Delassus, 2005). Given the specific functions of core and peripheral systems of representation, the aim of the present study is to determine their respective roles for the perception of a vertical product line extension. To meet this objective, this paper is constructed in four steps. We first introduce the theoretical framework and the experiment conducted on six brands in the automotive sector. The results are then presented and discussed in relation to their theoretical, methodological and managerial implications.

\section{THEORETICAL FOUNDATIONS}

Vertical product line extensions, range level and halo effects

A vertical product line extension implies coexistence within a product category of multiple branded offers, differentiated according to price and service and perceived as such by individuals (Michel and Salha, 2005). The market segment is here defined as a group of homogeneous products in terms of product attributes (of similar form and function). In the automotive market, we may thus identify as segments "urban”, “sedan” and "road” with links to automobile size and distinct usage. For each of these segments, a consumer may perceive a range of products differentiated according to price and perceived product value. This definition refers to low, middle and high-end ranges found in most markets. ${ }^{1}$

A vertical product line extension strategy raises two basic questions: First, are brand associations systematically transferred to the brand extension or does this transfer depend on

\footnotetext{
${ }^{1}$ P. Moati and M. Ranvier (2007), “Contrainte budgétaire des ménages, segmentation des marchés et stratégies de la grande distribution”, $\mathrm{N}^{\circ} \mathrm{C} 235$, Cahier de recherche du CREDOC.
} 
range levels of the product? Second, does this transfer increase or decrease the strength of linkages between brand association and vertical extensions? For example, does the Peugeot brand image impact the 107, 307 or 607 models equally, given that these models are in different range levels? Are there then, brand associations of Peugeot which are transferred to the various models regardless of the range level? These issues require a distinction between product and brand performance and invoke the concept of brand halo effects.

Considering the brand and the product as separate components of a single offer, Srinivasan (1979) postulated that consumers pay to use a brand independently of the product. In this way, brand equity is likely to vary from one product and category to another, as suggested by Park and Srinivasan (1994). Brand equity is thus defined as the "value added" by a trademark (Farquhar, 1989). In order to capture this added value, it becomes necessary to distinguish the "halo effect" of the brand on the collection of product attributes and the brand's “direct effect” on overall product preference (Barwise, 1993; Erdem and Swait, 1998; Park and Srinivasan, 1994). In the light of such a distinction, our research focuses on how far consumer brand perceptions influence the perception of vertical extensions via a "halo effect". Our research proposes to clarify this issue using the Central Nucleus Theory (Abric, 1994)

\section{Brand core system and brand image}

One of the first questions that arises is the extent to which brands embody social representations. According to Moscovici (1976), three conditions must be present for the emergence of an object as a social representation: dispersion of information suggesting that individuals do not have exhaustive knowledge of the subject matter, inferential pressures which lead individuals to take a position with regard to an object on the basis of partial information, and finally, increased attention arising from the interest implied as a result of discussions and related communications. These three conditions are satisfied by certain brands, especially those of high awareness among the population studied. Indeed, consumers often have only partial knowledge of brands, including those they use regularly (Korchia, 2004), and are thus led to infer the quality of proposed products on the basis of this information and the communications campaigns to which they are exposed. On this basis, the 
Central Nucleus Theory has already demonstrated its relevance in the study of brand images (Michel, 1999).

This conceptual framework suggests a brand image as a structure organized around a core and a peripheral system. The distinction between central and peripheral associations is both qualitative and functional (Abric 1994). From a qualitative point of view, central associations are defined as invariable because they are necessarily associated with the brand by a large majority of the members of the subject population. The core system includes a brand's defining attributes; in other words, the sufficient and necessary attributes for consumer identification. In contrast, peripheral associations are variable in that they are often, but not always, associated with the brand. Central and peripheral associations perform functions arising from this qualitative distinction. The invariability of central associations makes them resistant to change and independent of context, allowing them to fulfill structural and organizational functions with respect to the brand; they determine brand meaning. The variability of peripheral associations makes them dependent on context, allowing them in this way to provide adaptive and defensive functions (they buffer the core system). These theoretical foundations allow us to better understand brand halo effects.

According Riezebos (1994) a brand halo effect is the difference in perceived values between branded and generic (unbranded) products. From this perspective, the brand is seen as a signal that allows consumers to make inferences about the attributes of a branded product (Erdem and Swait, 1998). Indeed, from a cognitive point of view, product brand affiliation activates not only a categorization process (the brand will be perceived as a category of which the product is an examplar), but a process of attribution according to which certain category (brand) attributes will be transferred to the product. The principal structural and functional category models agree on the interdependence of these two processes (Murphy, 2002). Indeed, the categorization process itself assumes the attribution of category properties to the product examplar. Such a transfer, however, does not apply equally to all the properties of the category and the transfer depends, among other things, on the context in which the category is activated (Barsalou, 1999). Here, the Central Nucleus Theory offers a conceptual framework that can predict what brand associations will be transferred systematically to the extension product as well as the consequences of this transfer for the strength of the link between the extension product and the brand associations. 
More specifically, since the central associations are necessarily (and invariably) related to the brand, it can be argued that they are systematically transferred to the branded products. Moreover, central associations are more context-dependent than peripheral associations (Flament, 1995), allowing them to play a structural role with respect to perceptions of the social construct. As such, the transfer of central associations to the extension product strengthens linkages to the vertical extension, regardless of the product's position within the product line. In this respect, central associations become permanent features of a brand's halo effect to be positively and systematically transferred to the vertical extension.

- H1a: Central associations are transferred to the product line extension, regardless of the range level.

- H1b: The brand name revelation reinforces the evaluation of product line extension, for the central associations, regardless of the range level.

As peripheral associations are not necessarily related to the brand (conditionality), it is assumed that the transfer of peripheral associations among branded products is not systematic. Furthermore, peripheral associations are more sensitive to context than the central associations (Flament, 1995), thus allowing them to serve an adaptive role. In this way, the transfer of peripheral associations to an extension product could either strengthen or weaken linkages within the vertical extension: depending on the product's position within the product line, this link is strengthened when the brand is perceived as meeting consumer expectations, and on the contrary, weakened where the brand is perceived as unlikely to meet such expectations. Peripheral associations thus constitute the contextual elements of a brand's halo effect, for which the transfer to extension products depends on the range level of products considered and may be positive or negative.

- H2a: The transfer of peripheral associations to the extension product is less frequent than the transfer of central brand associations.

- H2b: The effect of the brand name revelation on the evaluation of the product line extension, for the peripheral associations, is moderated by the range level. 


\section{STUDY METHODOLOGY}

These four hypotheses were tested in the context of a vertical product line extension strategy within the automotive sector, an industry in which levels of product differentiation are clearly established. We present, on the one hand, the research design and sample population, and on the other hand, the measuring instruments used.

\section{Experimental design and sample population}

Brand awareness being a necessary condition in considering whether a brand constitutes an object of social representation, we limited our study to the six automotive brands with the highest volume of light vehicle sales in France for the year $2007:^{2}$ Citroën, Ford, Peugeot, Renault, Toyota and Volkswagen. To study brand halo effects with the product lines, five photographs of a concept-car were presented to the participants (See Appendix 1): three exterior photographs (front, back and profile) and two interior photos (one of the dashboard and a wide-angle shot of the passenger compartment). According to a first variable (range level), the concept-car was presented as low, medium or high-end. Participants were asked to rate the concept-car twice: first, without information as to the manufacturer (blind trial), and a second time, after having been informed that the concept-car would be marketed by one of the six brands studied (open trial). To limit the cognitive costs of the task, a delay of three days was introduced between the blind and open trials. The design allowed the study of perceived changes in the halo effect in a controlled manner and according to a before-and-after research design: three range levels (low, middle and high-end) $\mathrm{x}$ two tests (blind and open trials) x six brands (Citroën, Ford, Peugeot, Renault, Toyota, Volkswagen).

The questionnaire was administered face to face with a sample of 576 people with ordinary, non-commercial driver's licenses, strictly balanced in terms of gender (288 men and 288 women), age (288 people aged under 40 and 288 people aged 40 and over) and socio-

\footnotetext{
${ }^{2}$ Data provided by the CCFA (Comité des Constructeurs Français d'Automobiles or, Committee of French Automobile Manufacturers). Renault has a 21.48\% market share, Peugeot 16.92\%, Citroën 13.43\%, Volkswagen 6.91\%, Toyota 5.01\% and Ford 4.99\%.
} 
professional categories (288 SPC+ and 288 SPC-). Overall, the research design included 18 combinations of brand and range levels and 32 participants for each condition, balanced in terms of gender, age and socio-professional category.

\section{Range level as a control variable}

In the automotive sector, manufacturers distinguish three range levels, differentiated in terms of quality and price: low-end, mid-range and high-end. ${ }^{3}$ The present study manipulated the variable "range level" in order to evaluate the transfer of brand associations to the extension product. The model was pre-tested against a control sample of 96 consumers. For the pre-test, six concept-cars were selected: two low-end models (Scion and Daihatsu), two mid-range (Lancia and Lada) and two high-end (Accura and Buick). Participants were shown an average of five concept-car photos (See Appendix 1): three photographs of the automobile exterior (front, back and profile) and two photographs of the interior (dashboard and passenger compartment). For each of the concept-cars, participants were first asked which manufacturer (brand) would have produced the particular model shown, and then whether it was possible that the concept-car had been manufactured by any of the six manufacturers used in the study: Citroën, Ford, Peugeot, Renault, Toyota and Volkswagen. Responses were collected on a four-point scale including two levels of affirmation, "Certainly yes" and "Probably yes", and two levels of denial, "Probably not" and "Certainly not”. Finally, respondents were asked to indicate where in the range level the concept-cars would be positioned: low, middle or high-end. To simplify the categorization task, respondents were presented with examples of automobile models in each range level, following which they were asked to classify each concept-car in terms of one of three range levels: low, middle and high-end. The concept-cars chosen for the study (Buick, Lancia and Daihatsu) were chosen to satisfy two main criteria:

1. In as much as participants were not to be informed as to which manufacturers had designed the concept-cars, a condition of plausibility was necessary to ensure that the concept-cars could have been designed by any of the six manufacturers studied (See Table 1).

\footnotetext{
${ }^{3}$ Data supplied by the Committee of French Automobile Manufacturers (CCFA).
} 
2. Photographs must clearly identify differentiated price and quality factors among the concept-cars as belonging to one of the three range levels considered: low, middle or high-end (See Table 1).

[ Insert Table 1 ]

\section{Measuring brand halo effects}

Brand image refers to a concept of perception in which brand associations are identified and evaluated on the basis of their strength, valence and uniqueness (Keller 1993). Associations represent the sum of what is known about a brand by a consumer, and identification leads to the functional, symbolic and experiential attributes associated with a brand. Such ad hoc brand measures focus on specific brand associations and do not allow comparisons of comparable attributes among competing brands. The social representation approach was chosen for this study because it provides a basis for comparing brands and brand extensions. On this theoretical basis, a series of studies (Tafani, Haguel and Household, 2007) showed that the image of a set of car manufacturers depended on the social representations held by individuals of what constituted a "good car". More specifically, these studies identified fourteen attributes strongly associated with a "good car" and showed that these associations are organized into five dimensions that reflect consumer expectations (See Appendix 2). These five dimensions include quality (standard equipment, finish and comfort), hedonism (status, stylishness, horsepower and aesthetics), economy (price and price/value), confidence (reliability, safety and engineering) and novelty (originality and innovation). The present study is placed in the continuation of this work and proposes to measure the brand halo effect on these fourteen attributes.

A brand's halo effect was measured as the difference between the participants' judgment of a generic concept-car versus the same concept but as a branded line extension. Thus, participants were asked twice to evaluate the concept-car in the low, middle and highend ranges: once, without information about the design and manufacture (the blind trial) and a second time, after being informed that the concept-car would be marketed by one of the brands (open trial). Both assessments focused on the social representations summarized by the fourteen attributes of a "good car" (See Appendix 3) and collected on 11-point scales, from 
“0” for the negative qualification to " 10 ” for its opposite. Thus, “equipment” was evaluated as between “0” (very poorly equipped) and “10” (very well equipped), “comfort” was evaluated as between "0" for (very uncomfortable) and "10" for (very comfortable), and so on. It was considered that brands have halo effects to the extent that differences are observed in attribute associations between blind and open trials: the greater the significance of the observed differences, the greater the transference from the brand to brand extension. Finally, the observed differences between blind and open trials allow us to determine whether a brand strengthens (positive difference) or weakens (negative difference) the relationship between the associated attribute and the product extension studied.

\section{Measuring the central nucleus of the brand}

Central brand associations are those attributes which a majority of brand users would consider inseparable from the brand experience. The measure used to isolate central association is a test based on the logic of dual-negation. According to this test, central brand associations are those associations which, when removed from the brand profile, result in massive brand rejection (Moliner, 1988). Using this technique, a question such as the following would be asked in order to test the central nature of the association, "reliability": “In your opinion, could a car that is not reliable be of brand X?" This procedure allowed examination of the centrality for fourteen attributes associated with a "good car" in the image of each of the six brands studied. These responses (96 per brand) were collected according to four-point scales which included two levels of acceptance "Very certainly yes" and “Definitely yes” and two levels of refutation “Certainly not” and "Very certainly not”. Here, refutations constitute an indication of the centrality of an association when called into question because a product that lacks a particular association is inconsistent with the considered brand. The chi-square test permitted identification of associations seen as inseparable from the brand by a large majority of individuals, and identification of the core system for each brand.

\section{RESULTS}

Core and peripheral systems of car brands 
In order to identify the central associations of different automotive brands, the observed frequency of brand rejection in response to challenges to each of the fourteen associations (See Table 2) was compared to a standard chi-square test for which threshold inferences were set at two thirds (cf. Tafani and Bellon, 2003) because such a test is particularly dependent on the panel size.

\section{[ Insert Table 2 ]}

Given this procedure, overall results indicate that each brand image is organized around a distinct core system. Thus, it appears that the central associations for the Citroën brand clearly indicate economic concerns (affordability, value for money). Central associations for the Ford brand reconcile these concerns with an element of confidence: solidity. The same applies to Renault for which confidence is defined in terms of safety, while economic concerns are limited to value for money. However, the core systems for the Peugeot and Toyota brands contain only items related to confidence: safety, reliability and, for Toyota, a reputation for solidity. It appears then that the core systems for these two brands do not include elements of economic concern. This finding suggests that Peugeot and Toyota lose in terms of economic attractiveness what they gain in consumer confidence. The same is true of Volkswagen whose core systems revolve around confidence (safety, reliability and solidity) while including elements of hedonism (horsepower and stylishness) and quality (finish). These results demonstrate that social representations of a "good car" constitute a frame of reference which reflects the distinctive image of car brands in terms of consumer expectations.

\section{Evaluation of vertical product line extensions}

The results of the pre-test (blind trial) evaluations of the concept-car in terms of the fourteen attributes associated with the social representation of a "good car" are provided in Appendix 3. These data were subjected to examination by analysis of variance in order to evaluate the effect of product level (low, middle and high-end) on the extension product. These tests confirmed the significance of product level in terms of seven central associations (See Table 3): status, horsepower, comfort, engineering, standard equipment, security and price. As it happens, the high-end concept-car is judged more favorably than the low-end 
concept-car in terms of hedonism (horsepower and status), confidence (safety and solidity) and quality (comfort and standard equipment). The low-end concept-car, however, is considered more affordable than the up-market concept-car. Finally, the mid-range conceptcar occupies an intermediate position for each of these seven associations. These results indicate that participants clearly distinguish among the three concept-cars, not only in terms of price, but also in terms of benefits (quality, confidence and hedonism). This makes it possible to confirm that the three concept-cars are clearly perceived as differentiated vertical product line extensions.

\section{[ Insert Table 3 ]}

\section{Brand halo effects with regard to the range level}

The brand halo effect for a given association was measured as the difference between the assessments produced in pre- and post-test trials (blind and open trials). As a first step, we conducted a multivariate analysis of variance (Manova) according to the proposed analytical design, three (vertical positions) $\mathrm{x}$ six (brands) of the differences between these tests for each of the fourteen associations. This analysis reveals a main effect for vertical position (Wilks $\lambda$ $=2.50 ; \mathrm{p}<.0001$ ) and for the brand, (Wilks $\lambda=4.24 ; \mathrm{p}<.0001)$ indicating that overall, the significance of the brand halo effect varies depending on the range levels and the brand considered. Moreover, the interaction of range levels and brand was significant $(\lambda$ de Wilks $=$ 1.82; $\mathrm{p}<.01$ ) and indicated that the brand halo effect was moderated by the range level considered, which supported, therefore, hypothesis H2b. To complete this analysis and test our hypotheses concerning central and peripheral associations, using Student's t, we compared pre- and post-test assessments for each association and each vertical category and brand (See Table 4).

\section{[ Insert Table 4 ]}

The two central associations of the Citroën brand (affordability and value for money) are transferred to the line extension whatever the product level considered, with the effect of strengthening linkages between these associations and the extension product, regardless of the vertical product position. The same observation applies in the case of Ford, three central associations of Ford (solidity, value for money and affordability), Renault, two associations (value for money and safety), Peugeot, two associations (safety and reliability), Toyota, three 
associations (safety, reliability and solidity) and Volkswagen, six associations (safety, reliability, solidity, stylishness, horsepower and finish). Thus, for the 18 associations identified as central, there is transfer to the extension product for each of the three range levels - in other words, a total of 54 transfers - thus confirming hypothesis H1a. Furthermore, it appears that the systematic transfer strengthens the link between the central associations and the extension product, confirming hypothesis H1b. These results indicate that the central associations are permanent features of the brand halo effect and systematically improve the evaluation of the vertical extension.

With regard to peripheral associations, only three are transferred to extension product, regardless of vertical branding position. Thus, for the three range levels, the link between "product finish" and the extension product is reinforced for Volkswagen and reduced for the three French brands. For Volkswagen, the link between "standard equipment" and the extension product is reinforced, while the link between the extension product and "affordability" is diminished. This finding shows that certain peripheral associations are transferred to the extension product, regardless of the vertical position, which negates hypothesis H2a. We must, however, note that the majority of association transfers depend on the vertical range considered. Indeed, it appears that these associations are transferred to the extension product in only 59 of the 188 possible cases, or $31 \%$ of cases. It follows that peripheral associations are less systematically transferred than central associations (Chisquare $=79.35 ; \mathrm{p}<.0001)$. Moreover, correlation analysis shows that overall, the transfer of any type of association (central or peripheral) is positively related to their degree of centrality $\left(\mathrm{r}_{\mathrm{bp}}=.38\right)$ : the more central the association, the greater the transference to the extension product, suggesting that the transfer of brand associations to the product extension clearly depends upon the status of these associations.

Finally, we should note that when such transfers occur, they may, for comparable peripheral associations, strengthen or reduce linkages between the association and the extension product depending on the vertical range considered. This is, in fact, the case for the Peugeot and Renault brands' peripheral association, horsepower (See Table 5): product linkages are strengthened at the lower end of the vertical range but weakened at the upper range. This result is crucial because it illustrates the function of certain adaptive peripheral associations whose relationship with the line extension is likely to vary depending on the vertical range considered, thus confirming hypothesis $\mathrm{H} 2 \mathrm{~b}$. 


\section{[ Insert Table 5 ]}

\section{DISCUSSION AND CONCLUSION}

Several lessons can be learned from this research into theoretical, methodological and managerial fields. From a theoretical point of view, the distinction between halo effect and permanent and contextual associations illustrates the debate concerning the independence or dependence of brand-equity vis-à-vis the vertical product range. In this case, the results suggest that the core system of the brand forms the stable part of the halo effect (i.e., basis common to a whole range of values within a product category) to which one should add peripheral associations depending on the vertical range considered. This result confirms that central brand associations represent elements of brand definition independent of the context in which the brand is located. Thus, when a product extension is represented as an expression of the brand, this product is systematically assigned to the central brand associations. Moreover, this research illustrates the adaptive function of peripheral associations whose relationship with the product extension can be strengthened or weakened depending on the vertical position within the range. It appears however, that certain peripheral associations are marginally able to benefit from the systematic transfer to the brand extension, suggesting that not all peripheral associations fulfill the same adaptive role. Here, we should emphasize that peripheral associations for which systematic transfers were observed, presented high level of refutation, it means that these associations are very close to the brand's central system. This is not unlike the results reported by Flament (1995) who proposed to distinguish within the peripheral system, a first and second periphery (the first being closer to the brand core system than the second) and showed that contextual effects are more pronounced in the second periphery. We are thus invited to consider that it is the degree of centrality of an association that determines its contextual independence and therefore the conditions of transfer to the extension product: the more central the association, the more systematic the transfer. These findings call into question the fact that all elements should have the same peripheral functions and should thus lead us to focus more precisely on the specific roles of the first and second peripheries in the functioning of social representations.

From a methodological point of view, the present study shows that the elements associated with a "good car" provide a relevant framework for the study of images of 
automotive brands. This brand measure, however, promotes the identification of functional associations at the expense of more symbolic associations. It would be appropriate, therefore, to test these hypotheses using an ad hoc measure of brand image to ensure the transfer of more symbolic associations between the brand and its vertical product line extensions. This research, however, proposes a measure of the halo effect that helps to understand the impact of brand on the perceived attributes of the vertical extension. In fact, comparisons of the various assessments of branded and unbranded products can accurately determine whether a brand strengthens or weakens a brand image associated with a vertical product line extension.

Finally, from a managerial point of view, the distinction between central and peripheral associations provides an explanation as to how a vertical product line extension is vested systematically with some brand attributes (central brand associations), while other attributes (peripheral brand associations) depend on the vertical position within the product range. Taking the example of Peugeot, this research highlights the fact that reliability and security are transferred to vertical extensions of the Peugeot product line, regardless of position within the vertical range. We note, however, that for Peugeot brand affiliations, the relationship between horsepower and product extension is reinforced at the lower end but weakened in the high-end range. This result suggests that while Peugeot seems able to respond satisfactorily to the horsepower that people expect from a low-end car, this is not the case for higher-end vehicles. This conclusion is not unlike the commercial success of Peugeot in the first two range levels (with the launch of the 205, then the 206 and, more recently, the 307 and 407) and the difficulties the brand has encountered in higher-end range (the failure of the 605, and to a lesser extent, that of the 607). At this level, and within the context of a vertical product line extension, these results would allow identification of message elements on which communication campaigns should focus in order to ensure that line extension imagery matches consumer expectations for a given vertical product position. It might thus appear inappropriate to focus communications efforts on central brand associations because they are already invariably linked to the brand. On the other hand, it may be relevant to focus communications efforts on peripheral brand associations, particularly if the objective is to strengthen consumers' linkages between the brand and peripheral associations. As part of a Peugeot vertical product line extension at the high-end range, it would be important to strengthen the link between horsepower and brand to meet consumer expectations at this quality level. 
These conclusions are based on a study of the automotive market and fictitious vertical product line extensions combining, in a sense, the vertical range (price) and the size of the car. To overcome these limitations, future research should verify the validity of these findings in other markets and for vertical product line extensions specific to other brands. Indeed, the brands studied are associated with significant sales volumes and results might have been more marked if the study had focused on brands positioned in niche markets (e.g., Porsche, Mercedes or Jaguar). It would be important to take into account the positioning variable in order to strengthen the internal validity of this research. Finally, although this study has shown that halo effects may lead to improvements in or the diminishment of certain attributes of the vertical product line extension, it does not allow inference of linkages between halo effects and brand equity. As a result, subsequent studies should integrate the behavioral effects of brand equity to specify the relationship between association transfers, the evaluation of brand extensions and purchase intentions.

In the end, the Central Nucleus Theory helps to understand brand halo effects, and hence the principle for evaluating vertical extensions. It is clear that this is a key issue in brand management, especially to the extent that it helps define with greater relevance opportunities for product development and public communications.

\section{REFERENCES}

Abric J.-C. (1994), L’organisation interne des représentations sociales: système central et système périphérique, in C. Guimelli (Ed.), Structures et transformations des représentations sociales, Neuchâtel, Delachaux and Niestlé, 73-84.

Aimé I. (2007), L’impact des différentes stratégies de changement de nom de marque sur la représentation de la marque et l'attitude des consommateurs, Doctoral dissertation, University Paris Dauphine.

Barsalou L.W. (1999), Perceptual symbol system, Behavioral and Brain Sciences, 22, 4, 577660.

Barwise P. (1993), Brand-equity: snark or boojum?, International Journal of Research in Marketing, 10, 1, 93-104.

Delassus V. (2005), Stratégie d'abandon de marque: analyse des transferts des valeurs de la marque abandonnée vers la nouvelle marque, Doctoral dissertation, University of Lille 2 (École Supérieure des Affaires). 
Erdem T. and Swait J. (1998), Brand equity as a signaling phenomenon, Journal of Consumer Psychology, 7, 2, 131-157

Farquhar P.H. (1990), Managing brand equity, Journal of Advertising Research, 30, 4, RC7RC12.

Flament C. (1995), Approche expérimentale de type psychophysique dans l'étude d'une représentation, Cahiers Internationaux de Psychologie Sociale, 28, 4, 67-76.

Gochen W. and Yung-Ghien (2007), How the strength of parent brand associations influence the interaction effects of brand breadth and product similarity with brand extension evaluations, Journal of Product \& Brand Management, 16, 3, 334-341.

Keller K.L. (1993), Conceptualizing, measuring and managing customer-based brand equity, Journal of Marketing, 57, 1, 1-22.

Keller K.L. (2008), Strategic brand management, New Jersey, Prentice Hall.

Kim K. and Chhajed D. (2001), An experimental investigation of valuation change due to commonality in vertical product line extension, Journal of Product Innovation Management, 18, 4, 219-230.

Kim C., Lavack A. and Smith M. (2001), Consumer evaluation of vertical brand extensions and core brands, Journal of Business Research, 52, 3, 211-223.

Kirmani A., Sood S. and Bridges S. (1997), The ownership effect in consumer responses to brand line stretches, working paper, 97-128, Marketing Science Institute, Cambridge, MA.

Korchia M. (2004), Connaissance de la marque: concepts et mesures, Proceedings of the $20^{\text {th }}$ Congrès de l'Association Française de Marketing, Saint-Malo.

Michel G. (1999), L’évolution des marques: approche par la théorie du noyau central, Recherche et Applications en Marketing, 14, 4, 33-53.

Michel G. and Cegarra J.-J. (2002), Co-branding: conditions de succès du produit comarqué, Proceedings of the $18^{\text {th }}$ Congrès de l'Association Française de Marketing, Lille, May 2002.

Michel G. and Salha B. (2005), L'extension de gamme verticale: clarification du concept, Recherche et Applications en Marketing, 20, 1, 65-78.

Moliner P. (1988), Validation expérimentale de l'hypothèse du noyau central des représentations sociales, Bulletin de Psychologie, 41, 387, 759-762.

Moliner P. (1996), Images et représentations sociales, Grenoble, Presses Universitaires de Grenoble. 
Moscovici S. (1976), La psychanalyse, son image et son public, Paris, Presses Universitaires de France.

Murphy G.L. (2002), The big book of concepts, Cambridge, MIT Press.

Park C.S. and Srinivasan V. (1994), A survey-based method for measuring and understanding brand-equity and its extendibility, Journal of Marketing Research, 31, 2, 271-288.

Randall T., Ulrich K. and Reibstein D. (1999), Capital marque et étendue verticale de la ligne de produits, Recherche et Applications en Marketing, 14, 3, 79-105.

Riezebos H.J. (1994), Brand-added value: theory and empirical research about the value of brands to consumers, Delft, Eburon Publishers.

Srinivasan S.V. (1979), Network models for estimating brand-specific effects in multiattribute marketing models, Management Science, 25, 1, 11-21.

Tafani E. and Bellon S. (2003), L’étude expérimentale des représentations sociales, in J.-C. Abric (Ed.), Méthodes d'étude des représentations sociales, Saint-Agne, Erès, 255-277.

Tafani E., Haguel V. and Ménager A. (2007), Des images de marque aux représentations sociales des marques: une application dans le secteur de l'automobile, Cahiers Internationaux de Psychologie Sociale, 73, 27-46. 
High-End Range

Mid-Range

Low-End Range

\begin{tabular}{|c|c|c|c|c|c|c|}
\hline Concept-Car & Buick & Accura & Lancia & Lada & Daihatsu & Scion \\
\hline Recognition & $0 \%$ & $0 \%$ & $2 \%$ & $0 \%$ & $0 \%$ & $0 \%$ \\
\hline \multicolumn{7}{|l|}{ Association* } \\
\hline Citroën & $52 \% \mathrm{a}$ & $48 \% \mathrm{a}$ & $68 \% a$ & $52 \% a$ & $72 \% a$ & $53 \% \mathrm{ab}$ \\
\hline Ford & $66 \% \mathrm{a}$ & $64 \%$ b & $65 \% \mathrm{a}$ & $69 \% \mathrm{~b}$ & $64 \% \mathrm{a}$ & $54 \%$ ab \\
\hline Peugeot & $53 \% \mathrm{a}$ & $49 \% \mathrm{a}$ & $58 \% \mathrm{a}$ & $53 \%$ a & $66 \% \mathrm{a}$ & $46 \% \mathrm{a}$ \\
\hline Renault & $54 \% \mathrm{a}$ & $55 \% \mathrm{ab}$ & $56 \%$ a & $67 \% \mathrm{~b}$ & $70 \% \mathrm{a}$ & $62 \% \mathrm{~b}$ \\
\hline Toyota & $64 \% \mathrm{a}$ & $62 \% \mathrm{~b}$ & $64 \% \mathrm{a}$ & $51 \% a$ & $70 \% \mathrm{a}$ & $66 \% \mathrm{~b}$ \\
\hline Volkswagen & $61 \% \mathrm{a}$ & $58 \% \mathrm{ab}$ & $56 \%$ a & $67 \% \mathrm{~b}$ & $61 \% \mathrm{a}$ & $48 \% \mathrm{a}$ \\
\hline \multicolumn{7}{|l|}{ Categorization } \\
\hline High-End Range & $88 \%$ & $66 \%$ & $10 \%$ & $33 \%$ & $0 \%$ & $0 \%$ \\
\hline Mid-Range & $12 \%$ & $34 \%$ & $84 \%$ & $59 \%$ & $11 \%$ & $45 \%$ \\
\hline Low-End Range & $0 \%$ & $0 \%$ & $6 \%$ & $8 \%$ & $89 \%$ & $55 \%$ \\
\hline
\end{tabular}

*In a same column, association frequencies with different subscripts differ significantly $(p<.05)$ according to the Chi $^{2}$ test.

Table 1. Rate of recognition, probability of association to the brands and categorization in a range level. 
Table 2. Refutation frequency for the challenged associations.

\begin{tabular}{|c|c|c|c|c|c|c|}
\hline & CITROEN & FORD & PEUGEOT & RENAULT & TOYOTA & VOLKSWAGEN \\
\hline Safety & .61 & .64 & $.85^{*}$ & $.83 *$ & $.88^{*}$ & $.92 *$ \\
\hline Reliability & .60 & .64 & $.81 *$ & .59 & $.80 *$ & $.89 *$ \\
\hline Solidity & .41 & $.80 *$ & .58 & .62 & $.87 *$ & $.91 *$ \\
\hline Value for the money & $.82 *$ & $.80 *$ & .59 & $.83 *$ & .65 & .49 \\
\hline Affordability & $.81 *$ & $.84 *$ & .63 & .60 & .42 & .32 \\
\hline Horsepower & .36 & .52 & .60 & .62 & .67 & $.83 *$ \\
\hline Finishes & .41 & .49 & .54 & .50 & .66 & $.87 *$ \\
\hline Stylishness & .48 & .48 & .64 & .57 & .58 & $.82 *$ \\
\hline Comfort & .67 & .55 & .70 & .54 & .61 & .71 \\
\hline Equipment & .42 & .41 & .58 & .49 & .68 & .69 \\
\hline Originality & .64 & .48 & .56 & .60 & .53 & .52 \\
\hline Innovation & .61 & .47 & .54 & .55 & .51 & .60 \\
\hline Aesthetics & .35 & .39 & .54 & .49 & .59 & .65 \\
\hline Status & .48 & .42 & .51 & .46 & .57 & .70 \\
\hline
\end{tabular}

*Frequency significantly greater $(p<.05)$ than a $2 / 3$ norm, according to the Chi ${ }^{2}$ test.

\begin{tabular}{lcccc} 
& FORD & PEUGEOT & RENAULT & TOYOTA \\
\hline Safety & .64 &. $\mathbf{8 5 *}$ &. $\mathbf{8 3 *}$ &. $\mathbf{8 8 *}$ \\
Reliability & .64 & $.8 \mathbf{8 3}^{*}$ & .59 &. $\mathbf{8 0 *}$ \\
Solidity &. $\mathbf{8 0 *}$ & .58 & .62 &. $\mathbf{8 7 *}$ \\
Value for the money &. $\mathbf{8 0 *}$ & .59 &. $\mathbf{8 3 *}$ & .65 \\
Affordability &. $\mathbf{8 4 *}$ & .63 & .60 & .42 \\
Horsepower & .52 & .60 & .62 & .67 \\
Finishes & .49 & .54 & .50 & .66 \\
Stylishness & .48 & .64 & .57 & .58 \\
Comfort & .55 & .70 & .54 & .61 \\
Equipment & .41 & .58 & .49 & .68 \\
Originality & .48 & .56 & .60 & .53 \\
Innovation & .47 & .54 & .55 & .51 \\
Aesthetics & .39 & .54 & .49 & .59 \\
Status & .42 & .51 & .46 & .57 \\
\hline
\end{tabular}




\begin{tabular}{|c|c|c|c|c|}
\hline & \multicolumn{2}{|c|}{ Mean } & $F(2,558)$-value & p-value \\
\hline Comfort & $\begin{array}{l}\text { Low-End Range } \\
\text { Mid-Range } \\
\text { High-End Range }\end{array}$ & $\begin{array}{l}6,61 \\
7,36 \\
7,81\end{array}$ & 13,77 & $\mathrm{p}<.0001$ \\
\hline Equipment & $\begin{array}{l}\text { Low-End Range } \\
\text { Mid-Range } \\
\text { High-End Range }\end{array}$ & $\begin{array}{l}5,71 \\
6,12 \\
6,37\end{array}$ & 3,95 & $\mathrm{p}<.02$ \\
\hline Aesthetics & $\begin{array}{l}\text { Low-End Range } \\
\text { Mid-Range } \\
\text { High-End Range }\end{array}$ & $\begin{array}{l}6,90 \\
7,27 \\
6,96\end{array}$ & 1,14 & ns \\
\hline Reliability & $\begin{array}{l}\text { Low-End Range } \\
\text { Mid-Range } \\
\text { High-End Range }\end{array}$ & $\begin{array}{l}6,91 \\
7,15 \\
7,27\end{array}$ & 1,09 & ns \\
\hline Finishes & $\begin{array}{l}\text { Low-End Range } \\
\text { Mid-Range } \\
\text { High-End Range }\end{array}$ & $\begin{array}{l}6,12 \\
6,40 \\
6,50\end{array}$ & 1,66 & ns \\
\hline Innovation & $\begin{array}{l}\text { Low-End Range } \\
\text { Mid-Range } \\
\text { High-End Range }\end{array}$ & $\begin{array}{l}6,28 \\
6,48 \\
6,23\end{array}$ & 0,44 & ns \\
\hline Originality & $\begin{array}{l}\text { Low-End Range } \\
\text { Mid-Range } \\
\text { High-End Range }\end{array}$ & $\begin{array}{l}5,21 \\
5,67 \\
5,38\end{array}$ & 1.31 & ns \\
\hline Affordability & $\begin{array}{l}\text { Low-End Range } \\
\text { Mid-Range } \\
\text { High-End Range }\end{array}$ & $\begin{array}{l}5,24 \\
3,96 \\
2,83\end{array}$ & 49,20 & $\mathrm{p}<.0001$ \\
\hline Horsepower & $\begin{array}{l}\text { Low-End Range } \\
\text { Mid-Range } \\
\text { High-End Range }\end{array}$ & $\begin{array}{l}6,34 \\
7,10 \\
7,57\end{array}$ & 15,18 & $\mathrm{p}<.0001$ \\
\hline Value for the money & $\begin{array}{l}\text { Low-End Range } \\
\text { Mid-Range } \\
\text { High-End Range }\end{array}$ & $\begin{array}{l}5,08 \\
4,89 \\
4,58\end{array}$ & 1,82 & ns \\
\hline Safety & $\begin{array}{l}\text { Low-End Range } \\
\text { Mid-Range } \\
\text { High-End Range }\end{array}$ & $\begin{array}{l}6,29 \\
6,65 \\
6,94\end{array}$ & 3,71 & $\mathrm{p}<.03$ \\
\hline Solidity & $\begin{array}{l}\text { Low-End Range } \\
\text { Mid-Range } \\
\text { High-End Range }\end{array}$ & $\begin{array}{l}6,16 \\
6,56 \\
6,93\end{array}$ & 4,83 & $\mathrm{p}<.01$ \\
\hline Status & $\begin{array}{l}\text { Low-End Range } \\
\text { Mid-Range } \\
\text { High-End Range }\end{array}$ & $\begin{array}{l}6,63 \\
7,48 \\
8,11 \\
\end{array}$ & 22,19 & $\mathrm{p}<.0001$ \\
\hline Stylishness & $\begin{array}{l}\text { Low-End Range } \\
\text { Mid-Range } \\
\text { High-End Range }\end{array}$ & $\begin{array}{l}6,93 \\
7,14 \\
7,25\end{array}$ & 0,96 & ns \\
\hline
\end{tabular}

Table 3. Analysis of variance performed on the pre-test (blind-test) evaluations of concept-cars. 
Table 4. Mean value of the halo effect (difference between the post- and the pre-test evaluations)

depending on the considered association, range level and brand

\begin{tabular}{|c|c|c|c|c|c|c|c|}
\hline & & Citroën & Ford & Peugeot & Renault & Toyota & Volkswagen \\
\hline \multirow{14}{*}{ 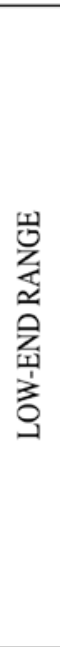 } & Comfort & .41 & .34 & .50 & .38 & .34 & .27 \\
\hline & Equipment & -.47 & -.41 & -.06 & -.38 & $.59 \%$ & $1.06^{\text {*al }}$ \\
\hline & Aesthetics & .06 & -.09 & -.06 & -.15 & -.06 & -.22 \\
\hline & Reliabikity & -.22 & .12 & $.78^{* * *}$ & .43 & $.75 * *$ & $1.06^{* * *}$ \\
\hline & Finish & $-.84^{\text {水水京 }}$ & $-.75^{* *}$ & -.34 & $-.62^{* 2 k}$ & .46 & $.87^{\text {冰水 }}$ \\
\hline & Innovation & -.31 & .10 & -.25 & -.25 & .25 & .07 \\
\hline & Originality & .03 & -.18 & -.12 & -.22 & -.07 & .19 \\
\hline & Affordability & $1.16 * *$ & $.78 * *$ & $.54 *$ & $.72 * *$ & .28 & $-.88^{* *}$ \\
\hline & Horsepower & .03 & .16 & 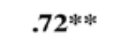 & $.69^{* * *}$ & .25 & $.94^{* * \cdots *}$ \\
\hline & Value for money & $.75^{* * *}$ & $1.10 * \%$ & $.78^{* * *}$ & $.91 * *$ & $.56 *$ & .28 \\
\hline & Safety & .15 & .22 & $.78^{* * *}$ & $.75^{* * *}$ & $.56 *$ & $.93 * *$ \\
\hline & Solidity & -.44 & $.84^{\text {*** }}$ & .47 & .41 & $1.16^{* * k}$ & 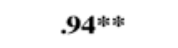 \\
\hline & Status & -.35 & -.31 & .25 & .06 & .44 & $.78^{* * * *}$ \\
\hline & Stylishness & -.06 & -.09 & .28 & .12 & .06 & $.53^{*}$ \\
\hline \multirow{14}{*}{$\begin{array}{l}\text { 岁 } \\
\text { 充 } \\
\text { 音 } \\
\text { 帘 }\end{array}$} & Comfort & $.84 * *$ & .41 & $.75^{* * *}$ & $.56^{*}$ & $.68 * *$ & $.50^{*}$ \\
\hline & Equipment & $-.66^{* * *}$ & $-.60^{*}$ & -.34 & -.31 & .44 & $.66^{* * *}$ \\
\hline & Aesthetics & -.19 & .28 & .15 & .06 & -.22 & .00 \\
\hline & Reliabikity & .22 & .31 & $.72^{* * *}$ & .34 & $.90 * *$ & $.84^{* * *}$ \\
\hline & Finish & $-1.03^{* * *}$ & $-.97 * *$ & -.16 & $-.53^{*}$ & $.63 * *$ & $.69^{* * *}$ \\
\hline & Innovation & .03 & -.10 & .21 & -.03 & -.28 & .31 \\
\hline & Originality & -.04 & .09 & .34 & -.12 & .12 & .03 \\
\hline & Affordability & $.90 * *$ & $.75 * *$ & .28 & .41 & -.15 & $-1.12 * *$ \\
\hline & Horsepower & $-.60^{*}$ & $-.53^{*}$ & .16 & .22 & .10 & $.78^{* * *}$ \\
\hline & Value for money & $.69 * *$ & $.72 * *$ & $.53 *$ & $.72 * *$ & .41 & -.06 \\
\hline & Safety & .06 & .13 & $.72^{* * *}$ & $.62 * *$ & $.71 * *$ & $.78^{* * *}$ \\
\hline & Solidity & -.31 & $.87 * *$ & .38 & .22 & $.81 * *$ & $.72 * *$ \\
\hline & Status & $-.69^{\text {*** }}$ & $-.63^{* *}$ & .00 & -.32 & .28 & $.69^{* * \cdots *}$ \\
\hline & Stylishness & .21 & -.22 & -.19 & -.07 & .34 & $.63^{\text {**ak }}$ \\
\hline \multirow{14}{*}{ 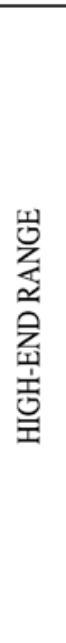 } & Comfort & $.69 * *$ & .44 & $.96^{* * *}$ & $.66 * *$ & $.56 *$ & $.78^{* * *}$ \\
\hline & Equipment & $-1.04^{* * *}$ & $-.85^{* * *}$ & -.53 & $-.53^{*}$ & .28 & $.78^{* * 2}$ \\
\hline & Aesthetics & -.12 & -.03 & -.16 & -.17 & .12 & -.16 \\
\hline & Reliabikity & .09 & .46 & $.63^{* * *}$ & .34 & $.78^{* * *}$ & $.72^{\text {*** }}$ \\
\hline & Finish & $-.72^{* * *}$ & $-.59 *$ & -.31 & $-.50 *$ & $.75 * *$ & $1.16 * *$ \\
\hline & Innovation & -.12 & -.16 & .12 & .37 & .38 & -.35 \\
\hline & Originality & .16 & -.03 & .15 & .32 & .37 & .06 \\
\hline & Affordability & $.75^{* *}$ & $.56 *$ & .16 & .09 & -.47 & $-1.44 * *$ \\
\hline & Horsepower & $-1.19^{* * *}$ & $-.72^{* * *}$ & $-.75^{* * *}$ & $-.69^{* * *}$ & $-.72^{* * *}$ & $.66^{* * 2 *}$ \\
\hline & Value for money & $.68 * *$ & $.66 * *$ & .32 & $.66 * *$ & .25 & -.31 \\
\hline & Safety & .25 & .41 & $.63^{* * *}$ & $.51 \%$ & $.87 * *$ & $1.13^{\text {*k }}$ \\
\hline & Solidity & .09 & $.50 *$ & .06 & .06 & $.56 \%$ & $.56^{*}$ \\
\hline & Status & $-.94^{* * *}$ & $-.91 * *$ & $-.53 *$ & $-.62^{* * *}$ & .12 & $.63^{*}$ \\
\hline & Stylishness & -.25 & .10 & .44 & -.35 & .31 & $.87 * *$ \\
\hline
\end{tabular}

${ }^{* *} p<.05,{ }^{*} p<.10$, according to the $t$-test 


\begin{tabular}{|c|c|c|c|c|c|c|c|}
\hline & & Citroen & Ford & Peugeot & Renault & Toyota & Volkswagen \\
\hline \multirow{6}{*}{ 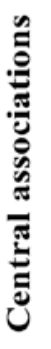 } & & Affordability & Affordability & Safety & Safety & Safety & Safety \\
\hline & & Value for money & Value for money & Reliability & Value for money & Reliability & Reliability \\
\hline & & & Solidity & & & Solidity & Solidity \\
\hline & & & & & & & Status \\
\hline & & & & & & & Horsepower \\
\hline & & & & & & & Stylishness \\
\hline \multirow{9}{*}{ 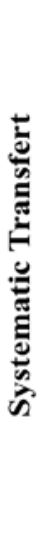 } & & Affordability + & Affordability + & Safety + & Safety + & Safety + & Safety + \\
\hline & & Value for money + & Value for money + & Reliability + & Value for money + & Reliability + & Reliability + \\
\hline & & & Solidity + & & & Solidity + & Solidity + \\
\hline & & & & & & & Status + \\
\hline & & & & & & & Horsepower + \\
\hline & & & & & & & Stylishness + \\
\hline & & & & & & & Equipment + \\
\hline & & Finishes - & Finishes - & & Finishes - & & Finishes + \\
\hline & & & & & & & Affordability - \\
\hline \multirow{11}{*}{ 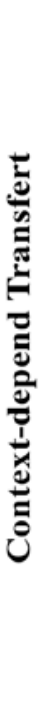 } & & & & Value for money + & Value for money + & Value for money + & \\
\hline & 善 跑 & & & Affordability + & Affordability + & Affordability + & \\
\hline & $\stackrel{2}{0}$ & & & Horsepower + & Horsepower + & Equipment + & \\
\hline & 8 & Comfort + & & Comfort + & Comfort + & Comfort + & Comfort + \\
\hline & $\stackrel{\bar{\pi}}{\check{\check{x}}}$ & Equipment - & Equipment - & Value for money + & Value for money + & Finishes + & \\
\hline & $\sum^{\frac{1}{3}}$ & Horsepower - & Horsepower - & & & & \\
\hline & 8 & Status - & Status - & & & & \\
\hline & & Comfort + & & Comfort + & Comfort + & Comfort + & Comfort + \\
\hline & 동 & Equipment - & Equipment - & & Equipment - & Finishes + & \\
\hline & $=$ & Horsepower - & Horsepower - & Horsepower - & Horsepower - & Horsepower - & \\
\hline & & Status - & Status - & Status - & Status - & & \\
\hline
\end{tabular}

Note : The signs + and - following the associations respectively indicate whether the transfert reinforces or reduces the linkage between the associations and the vertical extensions.

Table 5. Central and Peripheral Associations involved in the brand halo effect. 
Appendix 2. The social representation of a "good car": Factorial matrix after varimax rotation (Tafani, Haguel and Ménager, 2007).

\begin{tabular}{|c|c|c|c|c|c|}
\hline & Facteur 1 & Facteur 2 & Facteur 3 & Facteur 4 & Facteur 5 \\
\hline Equipment & ,852 &, 128 &, 113 & 059 &, 175 \\
\hline Comfort & ,794 &, 212 &, 121 & ,129 & ,186 \\
\hline Finishes & ,787 & ,103 & ,088 &, 045 &, 121 \\
\hline Aesthetics & ,689 & ,098 &, 284 & ,098 &, 258 \\
\hline Safety &, 145 &, 841 &,- 168 &, 113 &, 142 \\
\hline Solidity &, 084 & ,807 & ,096 &, 143 & ,098 \\
\hline Reliability &, 36 & ,774 &, 131 & 087 &, 042 \\
\hline Horsepower &, 154 &,- 204 & ,829 & ,129 &, 173 \\
\hline Status & ,178 & ,123 & ,785 &,- 109 & ,104 \\
\hline Stylishness &, 112 & ,068 & ,640 &, 083 & , 146 \\
\hline Affordability & ,138 &, 101 & ,184 & ,861 &, 124 \\
\hline Value for money &, 246 &, 089 &, 323 &, 742 &, 023 \\
\hline Innovation & ,172 & , 186 & ,176 & , 158 & ,774 \\
\hline Originality &, 064 &, 121 &, 098 &, 023 &, 743 \\
\hline $\begin{array}{l}\text { Explained } \\
\text { Variance }\end{array}$ & $19,92 \%$ & $15,49 \%$ & $14,73 \%$ & $10,18 \%$ & $10,05 \%$ \\
\hline
\end{tabular}


Appendix 3 : Pre- and post-test evaluations of concept-cars depending on the range level.

\begin{tabular}{|c|c|c|c|c|c|c|c|c|c|c|c|c|c|}
\hline & & \multicolumn{2}{|c|}{ Citroen } & \multicolumn{2}{|c|}{ Ford } & \multicolumn{2}{|c|}{ Peugeot } & \multicolumn{2}{|c|}{ Renault } & \multicolumn{2}{|c|}{ Toyota } & \multicolumn{2}{|c|}{ Volkswagen } \\
\hline & & $\begin{array}{l}\text { Pre- } \\
\text { Test }\end{array}$ & $\begin{array}{c}\text { Post- } \\
\text { Test }\end{array}$ & $\begin{array}{l}\text { Pre- } \\
\text { Test }\end{array}$ & $\begin{array}{c}\text { Post- } \\
\text { Test }\end{array}$ & $\begin{array}{l}\text { Pre- } \\
\text { Test }\end{array}$ & $\begin{array}{c}\text { Post- } \\
\text { Test }\end{array}$ & $\begin{array}{l}\text { Pre- } \\
\text { Test }\end{array}$ & $\begin{array}{c}\text { Post- } \\
\text { Test }\end{array}$ & $\begin{array}{l}\text { Pre- } \\
\text { Test }\end{array}$ & $\begin{array}{c}\text { Post- } \\
\text { Test }\end{array}$ & $\begin{array}{l}\text { Pre- } \\
\text { Test }\end{array}$ & $\begin{array}{c}\text { Post- } \\
\text { Test }\end{array}$ \\
\hline \multirow{14}{*}{ 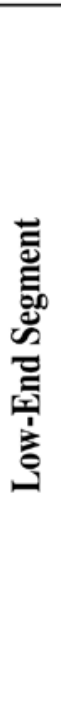 } & Aesthetics & 6.88 & 6.94 & 6.75 & 6.66 & 7.22 & 7.16 & 6.59 & 6.44 & 6.75 & 6.69 & 7.19 & 6.97 \\
\hline & Affordability & 5.72 & 6.88 & 5.44 & 6.22 & 5.12 & 5.66 & 5.19 & 5.91 & 4.84 & 5.12 & 5.16 & 4.28 \\
\hline & Comfort & 6.81 & 7.22 & 6.22 & 6.56 & 6.69 & 7.19 & 6.62 & 7.00 & 6.44 & 6.78 & 6.91 & 7.19 \\
\hline & Equipment & 5.50 & 5.03 & 5.53 & 5.12 & 5.78 & 5.72 & 6.03 & 5.66 & 5.94 & 6.53 & 5.47 & 6.53 \\
\hline & Finishes & 6.50 & 5.66 & 6.19 & 5.44 & 5.81 & 5.47 & 6.12 & 5.50 & 6.16 & 6.62 & 5.94 & 6.81 \\
\hline & Horsepower & 6.44 & 6.47 & 6.22 & 6.38 & 6.16 & 6.88 & 6.47 & 7.16 & 6.41 & 6.66 & 6.34 & 7.28 \\
\hline & Innovation & 6.31 & 6.00 & 6.09 & 6.19 & 6.41 & 6.16 & 5.91 & 5.66 & 6.31 & 6.56 & 6.62 & 6.69 \\
\hline & Originality & 5.25 & 5.28 & 5.56 & 5.38 & 5.03 & 4.91 & 5.22 & 5.00 & 5.19 & 5.12 & 5.00 & 5.19 \\
\hline & Reliability & 6.78 & 6.56 & 6.69 & 6.81 & 7.00 & 7.78 & 6.88 & 7.31 & 6.94 & 7.69 & 7.19 & 8.25 \\
\hline & Safety & 6.44 & 6.59 & 6.09 & 6.31 & 5.75 & 6.53 & 6.50 & 7.25 & 6.56 & 7.12 & 6.41 & 7.34 \\
\hline & Solidity & 5.81 & 5.38 & 6.19 & 7.03 & 5.94 & 6.41 & 6.53 & 6.94 & 6.12 & 7.28 & 6.34 & 7.28 \\
\hline & Status & 6.66 & 6.31 & 6.31 & 6.00 & 7.03 & 7.28 & 6.75 & 6.81 & 6.56 & 7.00 & 6.47 & 7.25 \\
\hline & Stylishness & 6.72 & 6.66 & 6.97 & 6.88 & 7.25 & 7.53 & 6.69 & 6.81 & 7.22 & 7.28 & 6.75 & 7.28 \\
\hline & Value for the money & 5.28 & 6.03 & 5.31 & 6.41 & 5.06 & 5.84 & 4.81 & 5.72 & 4.78 & 5.34 & 5.25 & 5.53 \\
\hline \multirow{14}{*}{ 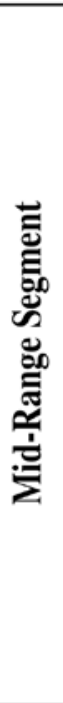 } & Aesthetics & 6.75 & 6.56 & 7.50 & 7.78 & 7.38 & 7.53 & 7.28 & 7.34 & 7.38 & 7.16 & 7.34 & 7.34 \\
\hline & Affordability & 4.16 & 5.06 & 3.81 & 4.56 & 3.84 & 4.12 & 4.12 & 4.53 & 3.81 & 3.66 & 4.03 & 2.91 \\
\hline & Comfort & 7.50 & 8.34 & 7.09 & 7.50 & 7.47 & 8.22 & 7.41 & 7.97 & 7.38 & 8.06 & 7.34 & 7.84 \\
\hline & Equipment & 5.75 & 5.09 & 6.22 & 5.62 & 6.50 & 6.16 & 6.34 & 6.03 & 6.12 & 6.56 & 5.78 & 6.44 \\
\hline & Finishes & 6.56 & 5.53 & 6.50 & 5.53 & 6.41 & 6.25 & 6.03 & 5.50 & 6.28 & 6.91 & 6.59 & 7.28 \\
\hline & Horsepower & 7.22 & 6.62 & 6.69 & 6.16 & 6.97 & 7.12 & 7.34 & 7.56 & 7.09 & 7.19 & 7.31 & 8.09 \\
\hline & Innovation & 6.78 & 6.81 & 6.22 & 6.12 & 6.88 & 7.09 & 6.41 & 6.38 & 6.66 & 6.38 & 5.97 & 6.28 \\
\hline & Originality & 5.16 & 5.12 & 5.72 & 5.81 & 5.69 & 6.03 & 6.03 & 5.91 & 5.91 & 6.03 & 5.53 & 5.56 \\
\hline & Reliability & 7.34 & 7.56 & 6.53 & 6.84 & 7.22 & 7.94 & 7.41 & 7.75 & 7.16 & 8.06 & 7.22 & 8.06 \\
\hline & Safety & 6.66 & 6.72 & 6.31 & 6.44 & 6.53 & 7.25 & 6.88 & 7.50 & 6.88 & 7.59 & 6.66 & 7.44 \\
\hline & Solidity & 6.53 & 6.22 & 6.47 & 7.34 & 6.50 & 6.88 & 6.31 & 6.53 & 6.88 & 7.69 & 6.69 & 7.41 \\
\hline & Status & 7.72 & 7.03 & 7.16 & 6.53 & 7.53 & 7.53 & 7.38 & 7.06 & 7.44 & 7.72 & 7.69 & 8.38 \\
\hline & Stylishness & 6.91 & 7.12 & 7.25 & 7.03 & 6.97 & 6.78 & 7.38 & 7.31 & 7.47 & 7.81 & 6.84 & 7.47 \\
\hline & Value for the money & 5.03 & 5.72 & 5.09 & 5.81 & 4.88 & 5.41 & 5.00 & 5.72 & 4.59 & 5.00 & 4.72 & 4.66 \\
\hline \multirow{14}{*}{ 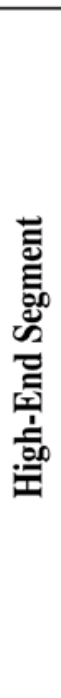 } & Aesthetics & 7.12 & 7.00 & 7.41 & 7.38 & 6.66 & 6.50 & 6.84 & 6.91 & 6.72 & 6.84 & 7.00 & 6.84 \\
\hline & Affordability & 3.16 & 3.91 & 2.78 & 3.34 & 2.47 & 2.62 & 2.69 & 2.78 & 2.53 & 2.06 & 3.38 & 1.94 \\
\hline & Comfort & 7.84 & 8.53 & 7.56 & 8.00 & 7.66 & 8.62 & 7.81 & 8.47 & 8.19 & 8.75 & 7.81 & 8.59 \\
\hline & Equipment & 6.16 & 5.12 & 6.41 & 5.56 & 6.22 & 5.69 & 6.62 & 6.09 & 6.44 & 6.72 & 6.38 & 7.16 \\
\hline & Finishes & 6.66 & 5.94 & 6.53 & 5.94 & 6.59 & 6.28 & 6.56 & 6.06 & 6.34 & 7.09 & 6.31 & 7.47 \\
\hline & Horsepower & 7.78 & 6.59 & 7.16 & 6.44 & 7.69 & 6.94 & 7.72 & 7.03 & 7.34 & 6.62 & 7.72 & 8.38 \\
\hline & Innovation & 6.00 & 5.88 & 6.44 & 6.28 & 6.19 & 6.31 & 6.19 & 6.56 & 6.19 & 6.56 & 6.38 & 6.03 \\
\hline & Originality & 5.62 & 5.78 & 5.31 & 5.28 & 4.88 & 5.03 & 5.84 & 6.16 & 4.88 & 5.25 & 5.72 & 5.78 \\
\hline & Reliability & 6.94 & 7.03 & 7.24 & 7.70 & 7.53 & 8.16 & 7.44 & 7.78 & 7.38 & 8.16 & 7.12 & 7.84 \\
\hline & Safety & 6.81 & 7.06 & 6.56 & 6.97 & 6.84 & 7.47 & 7.15 & 7.66 & 6.97 & 7.84 & 7.25 & 8.38 \\
\hline & Solidity & 6.72 & 6.81 & 6.88 & 7.38 & 7.06 & 7.12 & 6.88 & 6.97 & 7.00 & 7.56 & 7.03 & 7.59 \\
\hline & Status & 8.16 & 7.22 & 7.91 & 7.00 & 8.31 & 7.78 & 8.00 & 7.38 & 8.22 & 8.34 & 8.03 & 8.66 \\
\hline & Stylishness & 7.22 & 6.97 & 6.81 & 6.91 & 7.31 & 7.75 & 7.16 & 6.81 & 7.53 & 7.84 & 7.47 & 8.34 \\
\hline & Value for the money & 4.88 & 5.56 & 4.75 & 5.41 & 4.56 & 4.88 & 4.34 & 5.00 & 4.31 & 4.56 & 4.62 & 4.31 \\
\hline
\end{tabular}

